
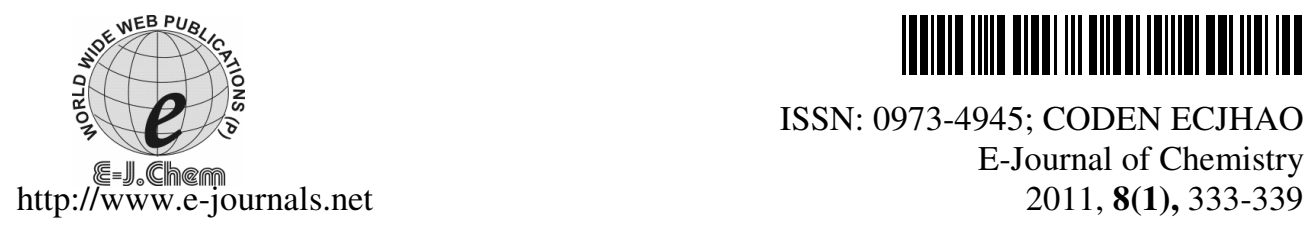

ISSN: 0973-4945; CODEN ECJHAO

E-Journal of Chemistry

2011, 8(1), 333-339

\title{
Equilibrium Isotherm Modeling, Kinetics and Thermodynamics Study for Removal of Lead from Waste Water
}

\author{
Z. Z. CHOWDHURY*, S.M. ZAIN and A.K. RASHID \\ Department of Chemistry \\ University Malaya, 50603-Malaysia \\ zaira_chowdhury@live.com
}

Received 10 May 2010; Revised 24 July 2010; Accepted 26 August 2010

\begin{abstract}
The low cost adsorbent palm oil fuel ash (POFA) derived from an agricultural waste material was investigated as a replacement of current expensive methods for treating wastewater contaminated by $\mathrm{Pb}$ (II) cation. Adsorption studies were carried out to delineate the effect of contact time, temperature, $\mathrm{pH}$ and initial metal ion concentration. The experimental data followed pseudo second order kinetics which confirms chemisorptions. The values of Langmuir dimensionless constant, $\mathrm{R}_{\mathrm{L}}$ and Freundlich constant, $1 / \mathrm{n}$ were less than 1 representing favorable process for adsorption. Thermodynamic parameters such as $\Delta \mathrm{G}^{\circ}, \Delta \mathrm{H}^{\circ}$ and $\Delta \mathrm{S}^{\circ}$, related to Gibbs free energy, enthalpy and entropy were evaluated. It was concluded that, chemically treated palm oil fuel ash (POFA) can be used successfully for adsorption of $\mathrm{Pb}$ (II) from aqueous solution.
\end{abstract}

Keywords: Kinetics, Isotherm, Lead, Thermodynamics.

\section{Introduction}

The presence of heavy metal ions in natural or industrial waste water and their hazardous impact has generated considerable concern in recent years. As a consequence of several man-made factors such as unplanned urbanization, industrialization, deforestation etc. along with anthropogenic activities, there is a progressive increase in soil and water pollution by heavy metals such as arsenic, chromium, copper, lead, mercury, cadmium, nickel, zinc and iron $e t c^{1-3}$. There are several methods for waste water treatment such as ion exchange, adsorption, chemical precipitation, oxidation, reduction and reverse osmosis ${ }^{4-6}$. However, many of these processes can be less effective or difficult for practical use due to their high price and sludge disposal problem. Therefore, to minimize this problem, lot of investigations has been carried out by the researchers to find out low cost, easily available materials from agricultural waste along with industrial by-products as adsorbents. Experimental adsorption 
properties of numerous waste biomass have been reported, such as- wheat bran ${ }^{7}$, saw dust ${ }^{8-10}$, penicillium biomass ${ }^{11}$ sunflower stalk ${ }^{12}$, spent grain ${ }^{13}$, onion skin $^{14}$, rice husk ${ }^{15-16}$, almond husk $^{17}$, modified barks ${ }^{18}$, banana pith ${ }^{19}$, rice milling by- products (hulls and brans) ${ }^{20}$ and soyabean hulls ${ }^{21}$ to remove heavy metals from waste water.

Malaysia has huge supply of waste biomass-generated from oil palm industries which consists of empty fruit bunch (EFB), palm shell (PS) and mesocarp fiber. This biomass is burnt in boiler to generate electricity which produces a lot of solid waste- palm oil fuel ash $(\text { POFA })^{22}$. Present work aims to remove $\mathrm{Pb}$ (II) cation from waste water by using chemically treated palm oil fuel ash and to investigate the physicochemical parameters involved during the sorption process. This research focuses on adsorption mechanisms, isotherm studies and evaluation of thermodynamic parameters for the sorption process of $\mathrm{Pb}$ (II) cation onto activated POFA from waste water.

\section{Experimental}

The palm oil fuel ash used here was taken from the middle of the flue tower where relatively fine ashes than the bottom layer is trapped before escaping from the burning chamber. The adsorbent thus obtained was sieved through sieve no $200 \mu \mathrm{m}$. It was washed with deionized water for several times to remove foreign particles and oven dried at $110^{\circ} \mathrm{C}$ over night. $50 \mathrm{~g}$ of POFA were activated with $10 \mathrm{~g}$ of $\mathrm{NaOH}$ dissolved in $250 \mathrm{~mL}$ deionized water by refluxing the mixture at $160{ }^{\circ} \mathrm{C}$ for $8 \mathrm{~h}$ in a round bottom flask with a magnetic stirrer placed inside it. The slurry obtained was filtered and the filter cake was repeatedly washed with deionized water until neutral $\mathrm{pH}$ of the filtrate was observed. Then it was dried in an oven at $110{ }^{\circ} \mathrm{C}$ for $12 \mathrm{~h}$ before use and stored in desiccators for further application.

All reagents were of AR grade chemicals. Stock solution of lead nitrate, having concentration of about $1000 \mathrm{mg} / \mathrm{L}$ was prepared by using double distilled water. Various concentrations of test solution of lead ranging from $10 \mathrm{mg} / \mathrm{l}$ to $70 \mathrm{mg} / \mathrm{L}$ were prepared by subsequent dilution of the stock solution while the initial $\mathrm{pH}$ was adjusted to 5.5 \pm 0.2 using a pH meter (Model CT No. CL 46, Toshniwal, India). Fresh dilution of the stock solution was done for each sorption study.

Each of the batch adsorption was carried out by contacting the $\mathrm{NaOH}$ modified POFA with the metal ion solution for a period of time in $100 \mathrm{~mL}$ plastic container by adding $0.2 \mathrm{~g}$ of adsorbent with $50 \mathrm{~mL}$ of different concentration of solution at $150 \mathrm{rpm}$. The residual concentration of $\mathrm{Pb}(\mathrm{II})$ was analyzed after definite interval of time until the system reached equilibrium by using atomic absorption spectrophotometer (Perkin - Elmer Model 3100). Experiments were conducted at $30{ }^{\circ} \mathrm{C}$ temperature to study the effect of initial $\mathrm{pH}$, contact time and initial metal ion concentration. To study the effect of temperature, each experiment was carried out in a thermoregulated water bath (Haake Wia Model, Japan) with shaker cover in order to prevent heat loss to the surroundings. The equilibrium adsorption amount, $\mathrm{q}_{\mathrm{e}}$ is calculated according to equation (1):

$$
q e=\frac{\left(C_{0}-C_{e}\right)}{W} V
$$

Here, $\mathrm{q}_{\mathrm{e}}$ is the adsorption amount of metal ion $(\mathrm{mg} / \mathrm{g})$ at equilibrium contact time, $\mathrm{W}$ is the weight of adsorbent $(\mathrm{g}), \mathrm{V}$ is the volume of solution $(\mathrm{mL})$. Each experiment was triplicated under identical condition. $C_{0}$ is the initial concentration of the solution $(\mathrm{mg} / \mathrm{L})$ and $\mathrm{C}_{\mathrm{e}}$ is the equilibrium concentration $(\mathrm{mg} / \mathrm{L})$. To minimize error, the mean value was used for calculation.

The removal efficiency of the metal ion was calculated by using equation (2):

$$
\text { Removal } \%=\frac{C_{0}-C_{e}}{C_{0}} \times 100
$$




\section{Results and Discussion}

\section{Surface characterization of the prepared adsorbent}

The phenomenon of adsorption is largely dependent on surface area and pore structure. The specific surface area can be greatly increased by alkali treatment. Table 1 depicts the physical properties of activated POFA.

Table 1. Physical properties of activated palm ash

\begin{tabular}{|c|c|c|c|c|c|}
\hline Adsorbent & $\begin{array}{c}\text { BET surface } \\
\text { area, } \mathrm{m}^{2} / \mathrm{g}\end{array}$ & $\begin{array}{l}\text { Micropore } \\
\text { area, } \mathrm{m}^{2} / \mathrm{g}\end{array}$ & $\begin{array}{c}\text { Micropore } \\
\text { volume, } \mathrm{cm}^{3} / \mathrm{g}\end{array}$ & $\begin{array}{c}\text { Mesopore } \\
\text { volume, } \mathrm{cm}^{3} / \mathrm{g}\end{array}$ & $\begin{array}{l}\text { Average pore } \\
\text { g diameter }\left(\mathrm{A}^{\circ}\right) \\
\end{array}$ \\
\hline $\begin{array}{l}\text { Activated } \\
\text { POFA }\end{array}$ & 467.1 & 561.9 & 0.199 & 0.349 & 46.9 \\
\hline
\end{tabular}

\section{Effect of initial metal ion concentration and contact time}

Figure 1 shows the effect of initial metal ion concentration with equilibrium contact time. The maximum equilibrium uptake, $\mathrm{q}_{\mathrm{e}}(\mathrm{mg} / \mathrm{g})$ for $\mathrm{Pb}(\mathrm{II})$ was increased from $2.211 \mathrm{mg} / \mathrm{g}$ to $11.8088 \mathrm{mg} / \mathrm{g}$ for $10 \mathrm{mg} / \mathrm{L}$ to $70 \mathrm{mg} / \mathrm{L}$ respectively. This is because when the initial concentration of the solution was increased, the mass transfer driving force became larger, resulting greater adsorption capacity. All the concentration range studied here reached equilibrium within 90 minutes. However, the experimental data were measured for 180 minutes to ensure that full equilibrium was achieved. The removal $\%$ of $\mathrm{Pb}$ (II) was increased from $88.84 \%$ to $92.23 \%$ when the temperature was increase from $30{ }^{\circ} \mathrm{C}$ to $70{ }^{\circ} \mathrm{C}$ for $10 \mathrm{mg} / \mathrm{L}$ solution.

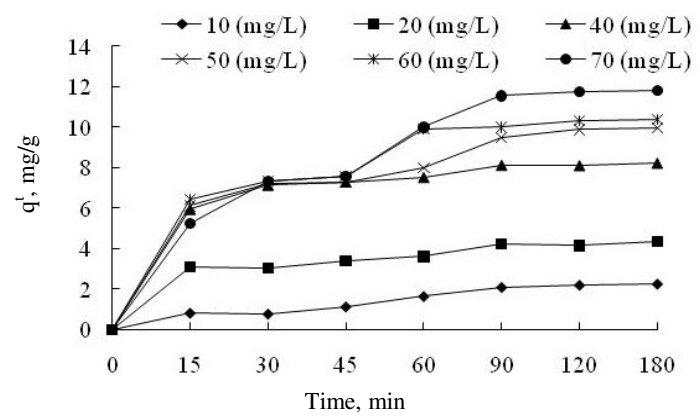

Figure 1. Effect of initial Lead ion concentration with equilibrium contact time at $30{ }^{\circ} \mathrm{C}$

From the above figure, it is clear that the amount adsorbed, $\mathrm{q}_{\mathrm{t}}(\mathrm{mg} / \mathrm{g})$ increased with time and after certain time and it reached a constant value beyond which the uptake was more or less same. At the equilibrium point, the amount of lead adsorbing and desorbing from the adsorbent was in a state of dynamic equilibrium. The amount adsorbed at equilibrium time reflected the maximum adsorption capacity of the adsorbent under the operating conditions applied. The results revealed that lead adsorption was fast at the initial stage of contact period and thereafter it became slower near the equilibrium point. The initial faster rate may be due to the availability of the uncovered surface area of the adsorbent. After a certain period of time, the reactive sites were exhausted and then it became difficult for the adsorbate (lead) to occupy the adsorbent surface. At that moment repulsive force was present between the adsorbate adsorbed onto the adsorbent and the fraction of adsorbate remaining into the solution. Similar trend was observed for adsorption of lead and zinc onto natural geothite ${ }^{23}$. 


\section{Effect of $\mathrm{pH}$ on equilibrium uptake}

Figure 2 shows the percentage of $\mathrm{Pb}(\mathrm{II})$ cation adsorbed onto the modified surface of POFA as a function of $\mathrm{pH}$. Maximum removal\% was achieved between $\mathrm{pH} 4$ to 6 . For $\mathrm{pH} 2$ to 3, the adsorption was low and it increased rapidly between $\mathrm{pH} 4$ to 6 . This phenomenon can be explained by the presence of $\mathrm{H}^{+}$ions into the solution. When $\mathrm{pH}$ was less than 4 , hydrogen protons were competing with metal ions for active binding sites on the surface of activated POFA. Fewer binding sites were available for $\mathrm{Pb}(\mathrm{II})$ cation to be adsorbed. As the $\mathrm{pH}$ was increases from 2 to 4 , there were fewer hydrogen protons in the solution. This means that there was less competition for binding sites. However, $\mathrm{pH}$ range of 4 to 6 was optimum for $\mathrm{Pb}$ (II) cation to be adsorbed by activated POFA. Thus adsorption of $\mathrm{Pb}$ (II) ions onto activated POFA was studied at $\mathrm{pH} 5.5 \pm 0.2$ for subsequent experiments at equilibrium. At $\mathrm{pH}$ 8 , the uptake of the cation started to increase. However, at higher $\mathrm{pH}$, the cumulative effect of adsorption and precipitation of the ions may contribute to higher $\%$ of removal ${ }^{24}$. Hence, the removal at high $\mathrm{pH}$ values was not studied.

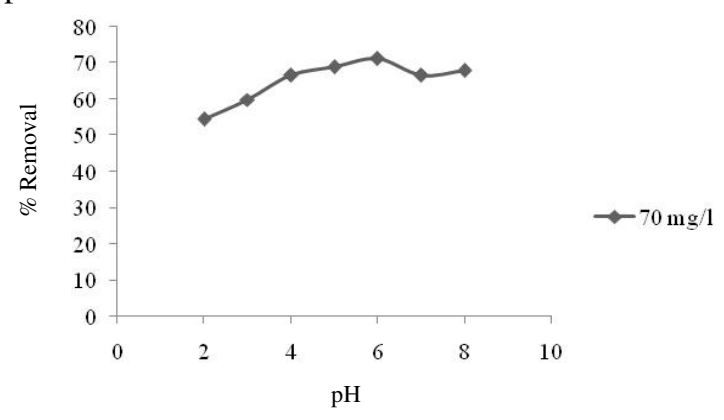

Figure 2. Effect of $\mathrm{pH}$ on removal \% of lead: $0.2 \mathrm{~g}$ adsorbent agitated at $150 \mathrm{rpm}$ with $50 \mathrm{~mL}$ solution of $70 \mathrm{mg} / \mathrm{L}$ lead at $30^{\circ} \mathrm{C}$

\section{Study of adsorption kinetics}

The study of adsorption kinetics is the main factor for designing an appropriate adsorption system and quantifying the changes in equilibrium uptake with time. Pseudo second order model which deals with chemisorptions can be expressed by following equations (3) and (4):

$$
\begin{aligned}
& \frac{d q_{t}}{\left(q_{e}-q_{t}\right)^{2}}=k_{2} t \\
& \frac{d q_{t}}{q t}=k_{2}\left(q_{e}-q_{t}\right)^{2}
\end{aligned}
$$

Here, $\mathrm{q}_{\mathrm{e}}(\mathrm{mg} / \mathrm{g})$ and $\mathrm{q}_{\mathrm{t}}(\mathrm{mg} / \mathrm{g})$ are the amount adsorbed at equilibrium and at any time $\mathrm{t}, \mathrm{k}_{2}$ is the rate constants of pseudo second order reaction. The results obtained for adsorption of $\mathrm{Pb}$ (II) onto activated POFA was fitted with pseudo second order equation. Pseudo second order model provides correlation coefficient, $\mathrm{R}^{2}$ nearer to unity for all the concentration range studied here except $10 \mathrm{mg} / \mathrm{L}$. Moreover, the calculated values of $\mathrm{q}_{\mathrm{e}}(\mathrm{mg} / \mathrm{g})$ from pseudo second order agreed quite well with the experimental data. Hence it appears that, the system under consideration is more appropriately described by the pseudo second order model which was based on the assumption that the rate limiting step may be chemical sorption involving valency forces through sharing or exchange of electrons between sorbent and sorbate $\mathrm{e}^{25}$. The initial sorption rate, $\mathrm{h}\left(\mathrm{mg} \mathrm{g}^{-1} \mathrm{~min}^{-1}\right)$ is $\mathrm{k}_{2} \mathrm{q}_{\mathrm{e}}{ }^{2}$ for second order model. The kinetic parameters obtained are listed in Table 2. 
Table 2. Pseudo-Second order kinetic parameters for adsorption of $\mathrm{Pb}$ onto POFA

\begin{tabular}{cccccc}
\hline $\begin{array}{c}\text { Initial } \\
\begin{array}{c}\text { Concentration, } \\
\mathrm{mg} / \mathrm{L}\end{array}\end{array}$ & $\begin{array}{c}\mathrm{q}_{\mathrm{e}, \mathrm{cal}} \\
\mathrm{mg} / \mathrm{g}\end{array}$ & $\begin{array}{c}\mathrm{q} \mathrm{e}, \mathrm{exp} \\
\mathrm{mg} / \mathrm{g}\end{array}$ & $\begin{array}{c}\text { Rate } \\
\text { constant, } \mathrm{k}_{2,} \\
\mathrm{~g}-\mathrm{mg}^{-1} \mathrm{~min}^{-1}\end{array}$ & $\begin{array}{c}\mathrm{h}, \\
\mathrm{mg}_{-} \mathrm{g}^{-1} \mathrm{~min}^{-1}\end{array}$ & $\begin{array}{c}\text { Correlation } \\
\text { Coefficient } \mathrm{R}^{2}\end{array}$ \\
\hline 10 & 3.1847 & 2.2211 & 0.0047 & 0.0477 & 0.896 \\
20 & 4.6511 & 4.3435 & 0.0163 & 0.3526 & 0.995 \\
40 & 8.5470 & 8.2041 & 0.0174 & 1.2710 & 0.999 \\
50 & 10.9890 & 9.9693 & 0.0054 & 0.6521 & 0.994 \\
60 & 11.3636 & 10.3625 & 0.0063 & 0.8135 & 0.993 \\
70 & 13.8889 & 11.8088 & 0.0027 & 0.5208 & 0.987 \\
\hline
\end{tabular}

Study of adsorption isotherm models

The study of the adsorption isotherm plays an important role in the determination of the maximum capacity of adsorption. Langmuir Isotherm model is given by following equation (5):

$$
\begin{gathered}
q_{e}=\frac{q_{\max } K_{L} C_{e}}{1+K_{L} C_{e}} \\
\frac{C_{e}}{q_{e}}=\frac{1}{q_{\max } K_{L}}+\frac{1}{q_{\max }} C_{e}
\end{gathered}
$$

Here, $\mathrm{q}_{\mathrm{e}}$ is the amount of equilibrium uptake $(\mathrm{mg} / \mathrm{g}), \mathrm{C}_{\mathrm{e}}$ is the equilibrium cation concentration in solution $(\mathrm{mg} / \mathrm{L}), \mathrm{q}_{\max }$ is the maximum monolayer adsorption capacity of the adsorbent $(\mathrm{mg} / \mathrm{g})$, and $\mathrm{K}_{\mathrm{L}}$ is the Langmuir adsorption constant $(\mathrm{L} / \mathrm{mg})$. The essential characteristics of the Langmuir equation can be expressed in terms of a dimensionless factor, $\mathrm{R}_{\mathrm{L}}$ which is given below:

$$
R_{L}=\frac{1}{1+K_{L} C_{o}}
$$

$\mathrm{C}_{\mathrm{o}}$ is the highest initial cation concentration $(\mathrm{mg} / \mathrm{L})$. The parameter $\mathrm{R}_{\mathrm{L}}$ indicates the shape of isotherm and can be expressed as-

- Unfavorable $\left(\mathrm{R}_{\mathrm{L}}>1\right)$

- $\operatorname{Linear}\left(\mathrm{R}_{\mathrm{L}}=1\right)$

- Favorable $\left(0<\mathrm{R}_{\mathrm{L}}<1\right)$

- Irreversible $\left(\mathrm{R}_{\mathrm{L}}=1\right)$

The linear plots of Langmuir Isotherm at $30{ }^{\circ} \mathrm{C}$ temperature are shown by Figure 3 . The model parameters at $30^{\circ} \mathrm{C}, 50^{\circ} \mathrm{C}$ and $70^{\circ} \mathrm{C}$ are listed in Table 3 .

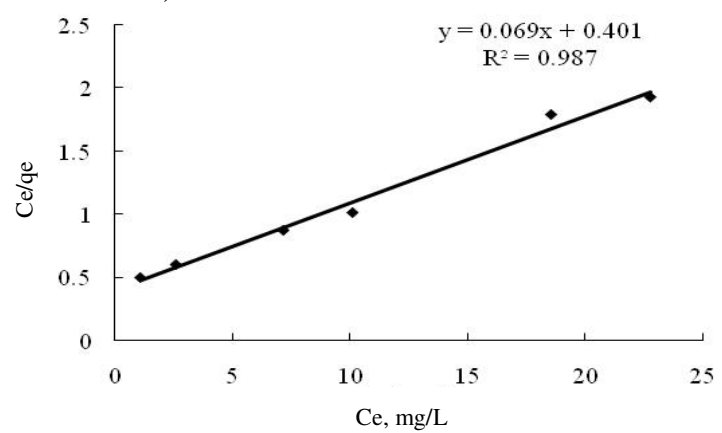

Figure 3. Adsorption isotherm obtained for $\mathrm{Pb}(\mathrm{II})$ sorption using Langmuir equation (linearized form) at $30{ }^{\circ} \mathrm{C}$ 
Table 3. Langmuir constants at different temperatures for adsorption of $\mathrm{Pb}$ onto POFA

\begin{tabular}{ccccc}
\hline $\begin{array}{c}\text { Temperature, } \\
{ }^{\circ} \mathrm{C}\end{array}$ & $\mathrm{R}_{\mathrm{L}}$ & $\begin{array}{c}\text { Maximum Adsorption } \\
\text { Capacity, } \mathrm{q}_{\mathrm{m}}, \mathrm{mg} / \mathrm{g}\end{array}$ & $\mathrm{K}_{\mathrm{L},} \mathrm{L} / \mathrm{mg}$ & $\mathrm{R}^{2}$ \\
\hline $30{ }^{\circ} \mathrm{C}$ & 0.76646 & 14.4927 & 0.1721 & 0.987 \\
$50{ }^{\circ} \mathrm{C}$ & 0.073975 & 15.6250 & 0.1788 & 0.987 \\
$70{ }^{\circ} \mathrm{C}$ & 0.052794 & 16.3934 & 0.2563 & 0.971 \\
\hline
\end{tabular}

The reveals that separation factor; $\mathrm{R}_{\mathrm{L}}$ is between $0.076-0.052$ for all the temperature range studied here. This represents favorable adsorption. Maximum monolayer adsorption capacity, $\mathrm{q}_{\mathrm{m}}$ $(\mathrm{mg} / \mathrm{g})$ increases with the increase of temperature from $30{ }^{\circ} \mathrm{C}$ to $70{ }^{\circ} \mathrm{C}$ which indicates endothermic nature of sorption ${ }^{26}$. The Freundlich equation can be written by following equation (8):

$$
q_{e}=K_{F} C_{e}^{\frac{1}{n}}
$$

Equation (8) can be linearized to yield equation (9):

$$
\ln q_{e}=\ln K_{F}+\frac{l}{n} \ln C_{e}
$$

Here, $\mathrm{K}_{\mathrm{F}}(\mathrm{mg} / \mathrm{g})(\mathrm{L} / \mathrm{mg})^{1 / n}$ and $1 / \mathrm{n}$ are Freundlich constants related to adsorption capacity and adsorption intensity of the adsorbent, respectively. Freundlich isotherm model parameters for both the metals at $30{ }^{\circ} \mathrm{C}, 50{ }^{\circ} \mathrm{C}$ and $70{ }^{\circ} \mathrm{C}$ are summarized in Table 4 .

Table 4. Freundlich Constants at different temperatures for adsorption of $\mathrm{Pb}$ onto POFA

\begin{tabular}{cccc}
\hline $\begin{array}{c}\text { Temperature, } \\
{ }^{\circ} \mathrm{C}\end{array}$ & $\begin{array}{c}\text { Affinity Factor, } \mathrm{K}_{\mathrm{F}}, \\
\mathrm{mg} / \mathrm{g}(\mathrm{L} / \mathrm{mg})^{1 / \mathrm{n}}\end{array}$ & $\begin{array}{c}\text { Heterogeneity } \\
\text { Factor, } 1 / \mathrm{n}\end{array}$ & $\mathrm{R}^{2}$ \\
\hline 30 & 2.4061 & 0.544 & 0.951 \\
50 & 2.6326 & 0.547 & 0.962 \\
70 & 3.4625 & 0.533 & 0.907 \\
\hline
\end{tabular}

From the above table, it is clear that Freundlich exponent; $1 / \mathrm{n}$ is less than one which represents favorable adsorption process. The good agreement of the experimental data with the Freundlich model indicates surface heterogeneity of the adsorbent. The values of adsorption capacity, $\mathrm{K}_{\mathrm{F}}$ increases with the increase of temperature. This represents that at higher temperature greater removal efficiency can be obtained. However, higher correlation coefficient, $\mathrm{R}^{2}$ value is obtained from Langmuir model than Freundlich model for all the temperature range studied here.

\section{Adsorption thermodynamics}

The thermodynamic parameters including change in Gibbs free energy, $\Delta \mathrm{G}^{\circ}$, enthalpy, $\Delta \mathrm{H}^{\circ}$ and entropy, $\Delta \mathrm{S}^{\circ}$ were determined by using following equations of (10) and (11):

$$
\begin{aligned}
& \ln K_{L}=\frac{\Delta S^{o}}{R}-\frac{\Delta H^{o}}{R T} \\
& \Delta G^{o}=R T \ln K_{L}
\end{aligned}
$$

Here, $\mathrm{K}_{\mathrm{L}}(\mathrm{L} / \mathrm{mg})$ is the constant obtained from Langmuir isotherm. $\mathrm{R}(8.314 \mathrm{~J} / \mathrm{mol} . \mathrm{K})$ is the universal gas constant and $\mathrm{T}$ is the temperature in Kelvin. $\Delta \mathrm{H}^{\circ}$ and $\Delta \mathrm{S}^{\circ}$ were calculated from the plot of $\ln \mathrm{K}_{\mathrm{L}}$ against $1 / \mathrm{T}$. The calculated values are given in Table 5 .

Table 5. Thermodynamic parameters at different temperature

\begin{tabular}{cccc}
\hline Temperature, ${ }^{\circ} \mathrm{K}$ & $\Delta \mathrm{G}^{\circ}, \mathrm{kJ} \mathrm{mol}^{-1}$ & $\Delta \mathrm{H}^{\circ}, \mathrm{kJ} \mathrm{mol}^{-1}$ & $\Delta \mathrm{S}^{\circ}, \mathrm{JK}^{-1}, \mathrm{~mol}^{-1}$ \\
\hline 303 & -4.4344 & & \\
323 & -4.6229 & 8.4636 & 0.0128 \\
343 & -3.9956 & & \\
\hline
\end{tabular}


The value of enthalpy change, $\Delta \mathrm{H}^{\circ}$ obtained here is $8.4636 \mathrm{~kJ} / \mathrm{mol}$. The positive value of enthalpy change confirms the endothermic nature of the adsorption process. The positive value of entropy, $\Delta \mathrm{S}^{\circ}$ corresponds to an increase in the degree of freedom of the adsorbed species. The positive value of $\Delta S^{\circ}$ also reflects that some changes occur in the internal structure of palm oil fuel ash during the adsorption process. Similar types of observation were reported by other researchers for removal of lead and chromium from waste water ${ }^{27}$. The magnitude of Gibbs free energy change, $\Delta \mathrm{G}^{\circ}$ obtained is negative suggesting that the adsorption is rapid and spontaneous. The negative value of $\Delta \mathrm{G}^{\circ}$ confirms feasibility of the process.

\section{Conclusion}

Palm oil fuel ash activated by sodium hydroxide has been shown to be a potentially useful material to remove $\mathrm{Pb}(\mathrm{II})$ from aqueous solutions. The rapid uptake and high sorption capacity along with its cheap cost make it a very attractive alternative sorbent material to treat waste water.

\section{Acknowledgment}

The authors are grateful for the financial support of this project by Research Grant (UMRG 056-09SUS) of University Malaya, Malaysia.

\section{References}

1. Bailey S E, Olin T J, Bricka R M and Adrian D D, Water Res., 1999, 33(11), 2469-2479.

2. Cay S, Uyanik A and Ozajik A, Sep Purif Technol., 2004, 38, 273-280.

3. Tee T W and Khan A R M, Environ Technol Lett., 1988, 9, 1223-1232.

4. Hashim M A and Chu K H, Chem Eng J., 2004, 97, 249-255

5. Horsfall M, Abia A A and Spiff A I, Afr J Biotechnol., 2003, 2(10), 360.

6. Okieimen F E and Onyenkpa V U, Biol Wastes, 1989, 29, 11.

7. Farajzadeh M A and Monji A B, Sep Purif Technol., 2004, 38(3), 197-207.

8. Yu B, Zhang Y, Shukla A, Shukla S S and Dorris K L, J Hazard Mater, 2000, B80, 33.

9. Raji C and Anirudhan T S, Indian J Chem Technol., 1997, 4, 157.

10. Sciban M and Klasnja M and Skrbic B, J Hazard Mater, 2006, 136(2), 266-271.

11. Niu H, Xu X S, Wang J H and Volesky B, Biotechnol Bioeng., 1993, 42, 785-787.

12. Sun G and Shi W, Ind Eng Chem Res., 1998, 37(4), 1324-1328.

13. Low K S, Lee C K and Liew S C, Process Biochem., 2000, 36(1-2), 59-64.

14. Kumar P and Dara S S, J Polym Sci Polym Chem Ed., 1981, 19, 397.

15. Khalid N, Ahmad S, Kiani S N and Ahmed J, J Sep Sci Technol., 1999, 34(16), 3139-3153.

16. Munaf E and Zein R, Environ Technol., 1997, 18(3), 359-362.

17. Hasar H, J Hazard Mater., 2003, B97, 49.

18. Gloaguen V and Morvan H, J Environ Sci Health, 1997, A32(4), 901.

19. Low K S, Lee C K and Leo A C, Biores Technol., 1995, 51(2-3), 227-231.

20. Marshall W E, Champagne E T and Evans W J, J Environ Sci Health A, 1993, 28(9), 1977.

21. Marshall W E, Wartelle L H, Boler D E, Johns M M and Toles C A, Biores Technol 1999, 69(3), 263-268.

22. Ahmad A A, Hameed B H and Aziz N, J Hazard Mater, 2007, 141, 70-76.

23. Abdus-Salam N and Adekola F A, AJST., Afr J Sci Technol., 2005, 6(2), 55-66.

24. Feng D, Deventer J S J and Aldrich C, Sep Purif Technol., 2004, 40, 61.

25. Ho Y S and McKay G, Process Biochem., 1999a, 34(5), 451-465.

26. Senthilkumaar S, Kalaamani P, Porkodi K, Varadarajan P R and Subburaam C V, Biores Technol., 2006, 97, 1618-1625.

27. Gupta V K and Imran A, J Colloid Interface Sci., 2004, 271, 321. 


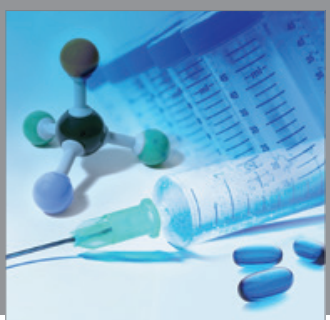

International Journal of

Medicinal Chemistry

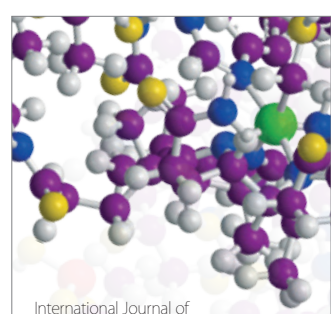

Carbohydrate Chemistry

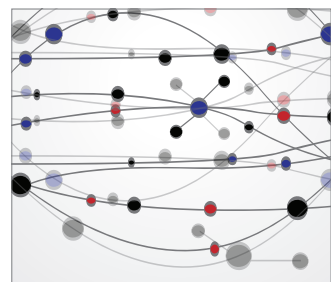

The Scientific World Journal
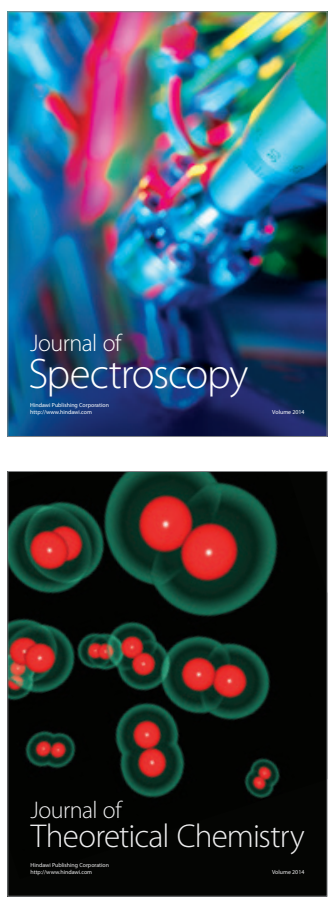
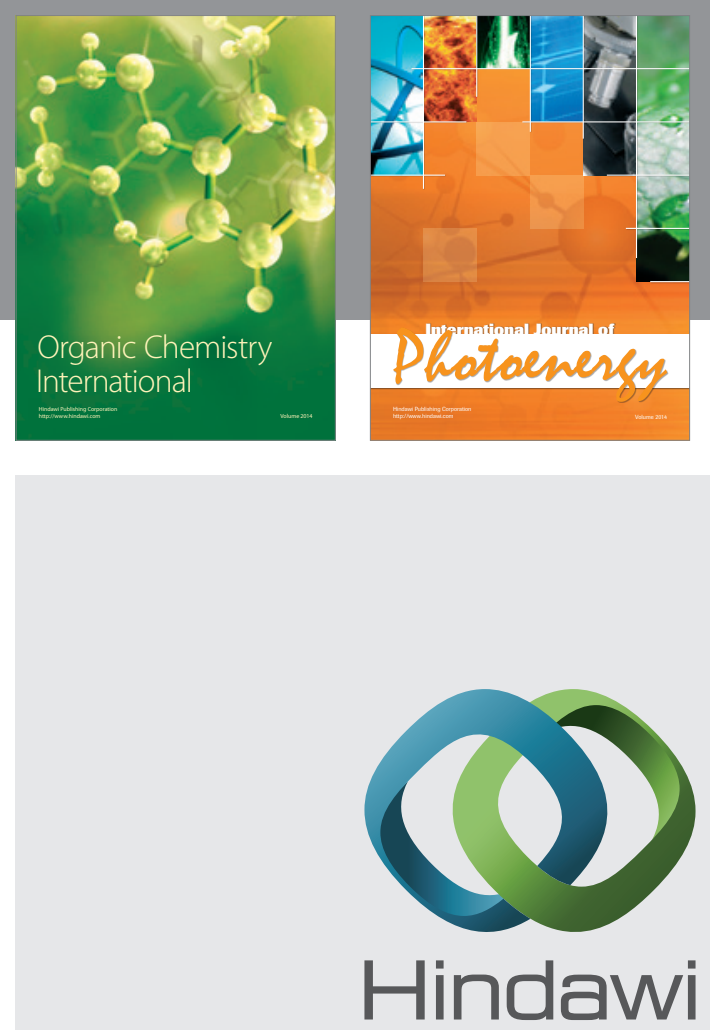

Submit your manuscripts at

http://www.hindawi.com
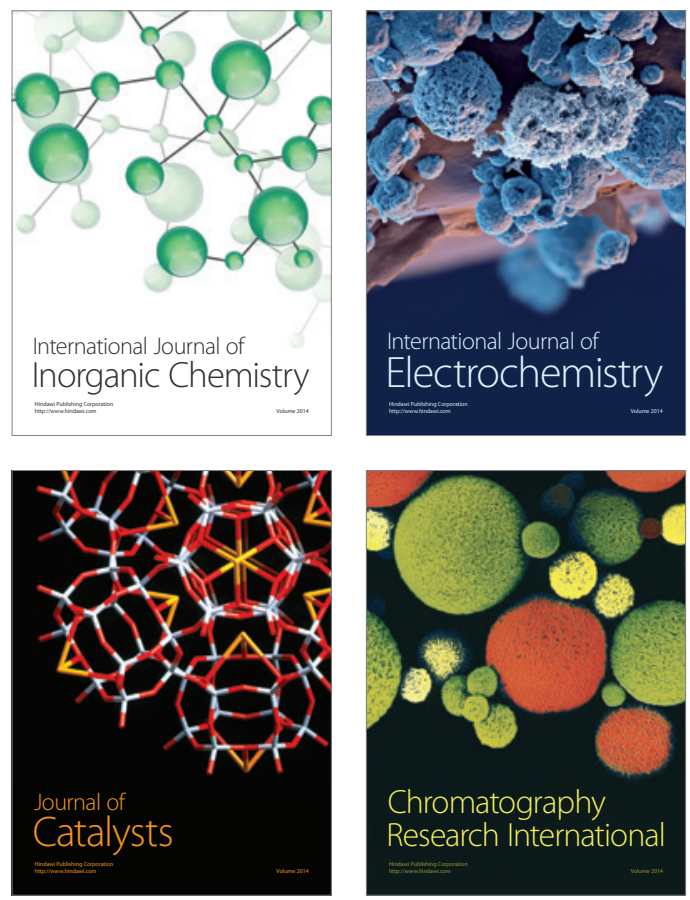
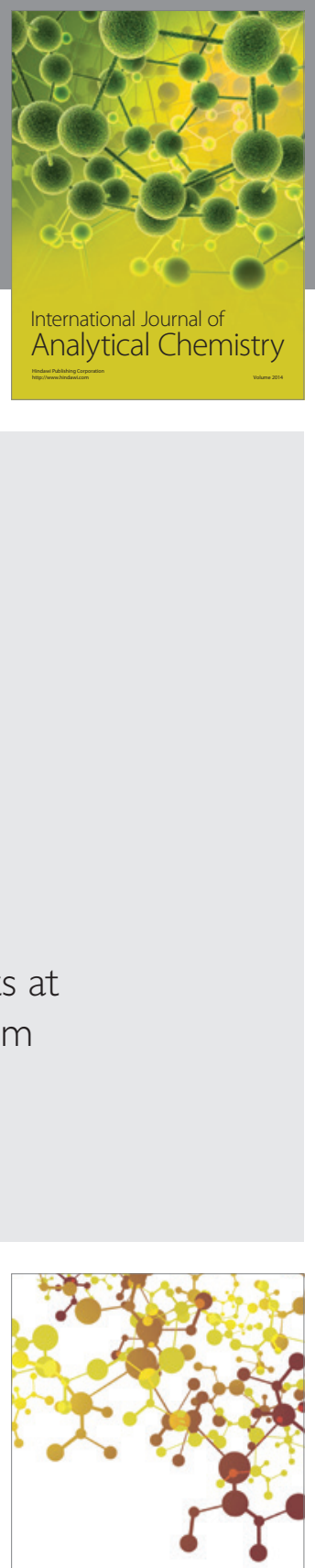

Journal of

Applied Chemistry
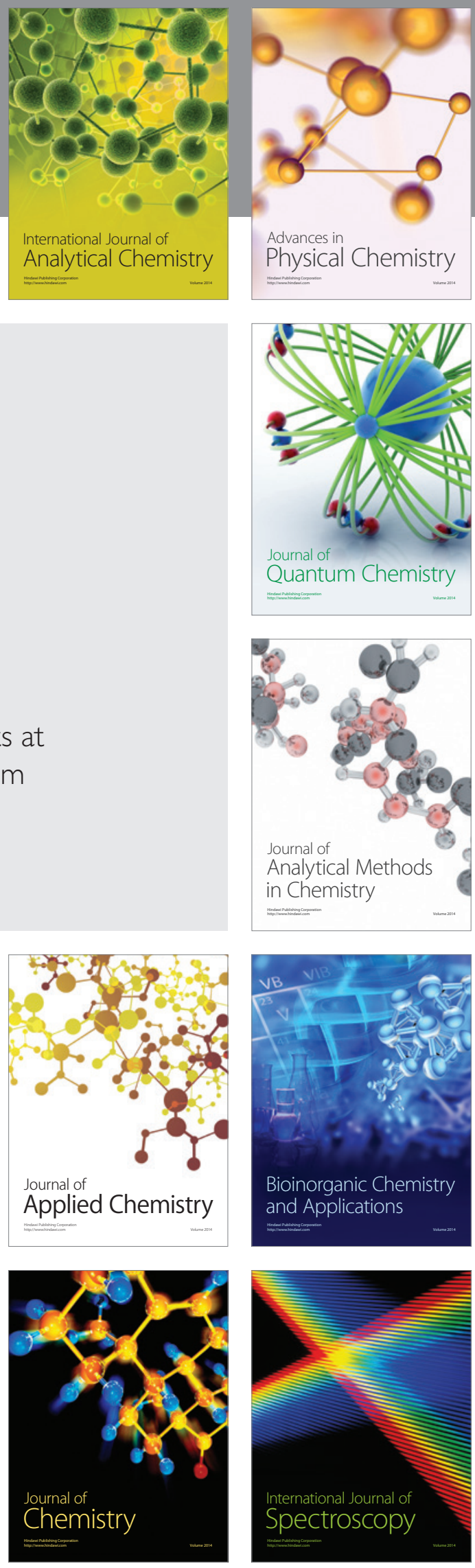